\title{
Postpartum Spinal Osteoporosis: An Unusual Cause of Low Back Pain
}

$$
\text { Postpartum Spinal Osteoporoz: Bel Ağrısının Nadir Bir Nedeni }
$$

\author{
Berrin Gündüz¹, Belgin Erhan¹, Merih Sarıdoğan², Nurgül Elbaşı³, Huri Özdoğan ${ }^{4}$ \\ 1Sağlık Bakanlığı İstanbul Fizik Tedavi Rehabilitasyon Eğitim ve Araştırma Hastanesi, 1. Fizik Tedavi ve \\ Rehabilitasyon Kliniği, İstanbul, Turkey \\ 2istanbul Üniversitesi Cerrahpaşa Tıp Fakültesi, Fizik Tedavi ve Rehabilitasyon Anabilim Dalı, İstanbul, Turkey \\ ${ }^{3}$ Bayrampaşa Belediyesi Rehabilitasyon Merkezi, İstanbul, Turkey \\ ${ }^{4}$ İstanbul Üniversitesi Cerrahpaşa Tıp Fakültesi, İç Hastalıkları Anabilim Dalı, Romatoloji Bilim Dalı, İstanbul, Turkey
}

Abstract
Postpartum spinal osteoporosis (PPSO) is a rare condition
characterized by osteoporosis associated with pregnancy. The
most common symptoms are low back pain and loss of height
due to vertebral compression fractures. It is observed in the last
trimester of pregnancy or subsequent to delivery. Herein; we
report 2 cases of PPSO who presented with low back pain in the
postpartum period, aiming to draw attention to this unusual
cause of low back pain. (Turk $J$ Rheumatol 2010; $25: 47-9$ )

Key words: Osteoporosis, pregnancy, postpartum, low back pain

Received: 20.05.2009

Accepted: 06.07.2009
Özet

Postpartum spinal osteoporoz (PPSO) gebelikle ilișkili osteoporozla karakterize ender görülen bir durumdur. En sık görülen semptomlar bel ağrısı ve vertebral kompresyon fraktürlerine bağlı boy kısalmasıdır. Gebeliğin son döneminde veya doğumdan hemen sonra görülür. Doğum sonrası dönemde bel ağrısı ile bașvuran iki olgumuzu sunarak bel ağrısı nedenleri içinde nadir görülen bu duruma dikkat çekmeyi amaçladık.

(Turk J Rheumatol 2010; 25: 47-9)

Anahtar sözcükler: Osteoporoz, gebelik, postpartum, bel ağrısı

Alındığı Tarih: 20.05.2009 Kabul Tarihi: 06.07.2009

\section{Introduction}

Postpartum spinal osteoporosis (PPSO) is an uncommon condition presenting with low back pain and is characterized by osteoporosis during late pregnancy or puerperium. Back pain and loss of height due to vertebral compression fractures are the most predominant symptoms. PPSO appears within 3 months after delivery of the first child; however, about $40 \%$ of the affected women experience the symptoms in their last trimester $(1,2)$.

Although the prevalence of PPSO is not known, it is thought to be a rare condition. There are about 100 cases of PPSO reported in literature (3); to our knowledge there are only few cases reported from Turkey (4-8). Our aim is to report 2 cases of PPSO who presented with low back pain in the postpartum period that were diagnosed with a few months delay, and to draw attention to PPSO in the lactating or pregnant patients who have low back pain.

\section{Case 1}

A 22 years old woman with back pain was admitted to our Physical Rehabilitation Medicine out-patient clinic. Her pain started 5 months ago, during the last trimester of her first pregnancy and increased in intensity in the postpartum period. With this complaint, she referred to a physician a month ago.

There was no peculiarity in her history other than the first delivery 3 months ago; she was breast-feeding her baby. She was thinly built (body mass index (BMI): $18.8 \mathrm{~kg} /$ $\mathrm{m}^{2}$ ) and had a slight increase in the dorsal kyphosis. The spinal processes in the lower thoracic and lumbar vertebrae were painful to palpation. The lumbar range of motion was painful in all directions.

Compressive fractures were detected in nearly all lumbar and thoracic vertebras on magnetic resonance imaging (MRI), requested elsewhere before admission to our

A part of this report was presented as an oral presentation in "5. Cerrahpaşa Lokomotor Sistem Günleri, Bel Ağrılarında Multidisipliner Yaklaşım, 2004, istanbul"

Address for Correspondence: Dr. Berrin Gündüz, Sağlık Bakanlığı İstanbul Fizik Tedavi Rehabilitasyon Eğitim ve Araştırma Hastanesi, 1. Fizik Tedavi ve Rehabilitasyon Kliniği, İstanbul, Turkey Phone: +90212442 2200 E-mail: gunduzberrin@gmail.com 
clinic; the fractures were most prominent in the lower thoracic and upper lumbar region (Figure 1). Bone mineral density (BMD) examination obtained with dualenergy X-ray absorbtiometry (DXA) (DXA-Lunar) revealed a $34 \%$ loss in the lumbar spine and $30 \%$ loss in the femoral region with respect to her age group (L2-4 Z-score -3.4, femur neck Z-score -2.4).

The patient was reevaluated for the etiology of secondary osteoporosis. She reported low intake of calcium in her diet. Thyroid function tests and serum levels of parathyroid hormone (PTH), 25-hydroxyvitamin D, osteocalcin were normal like the routine biochemical tests of alkaline phosphatase, calcium and phosphorus. She was diagnosed as PPSO; anti-resorptive treatment, in addition to calcium and vitamin D supplementation were started. She was informed about the diagnosis and the weaning. Her complaints resolved in the next month and her follow up still continues.

\section{Case 2}

Twenty-six years old female patient was admitted to our rheumatology out-patient clinic with the complaint of low back pain. Her pain started 4 months ago, immediately after delivery of her first child. The pain was aggravated by physical activity and diminished with nonsteroidal antiinflamatory drugs. Lumbar MRI was carried out with the prediagnosis of lumbar disc herniation. Vertebral deformities due to compression fractures were discovered both in the dorsal and lumbar vertabrae (Figure 2), and the patient was hospitalized for differential diagnosis.

The patient was a thin (BMl $20 \mathrm{~kg} / \mathrm{m}^{2}$ ), lactating mother. Thoracic and lumbar spinal processes were painful to palpation and she had pain with lumbar flexion and extension. Osteoporosis was diagnosed with DXA; Z-score was $-3,91$ at L1-4 and $-2,55$ at femoral neck (Hologic QDR-4500SL). The patient was evaluated for secondary osteoporosis. All the previously described laboratory tests were performed and were normal. The patient did not have any risk factors for osteoporosis in her history. Sacral stress fracture was discarded with plain X-ray and scintigraphy. She was diagnosed as PPSO and antiresorptive medication was prescribed, in addition to calcium and vitamin D supplementation. Her follow-up continues in the rheumatology out-patient clinic.

\section{Discussion}

Pregnant women complain of low back pain with increasing size of the gravid uterus. Pain starts commonly in the third trimester and it can last until the sixth month after delivery. Low back pain may be secondary to several biomechanical changes in the pelvic joints, ligaments and

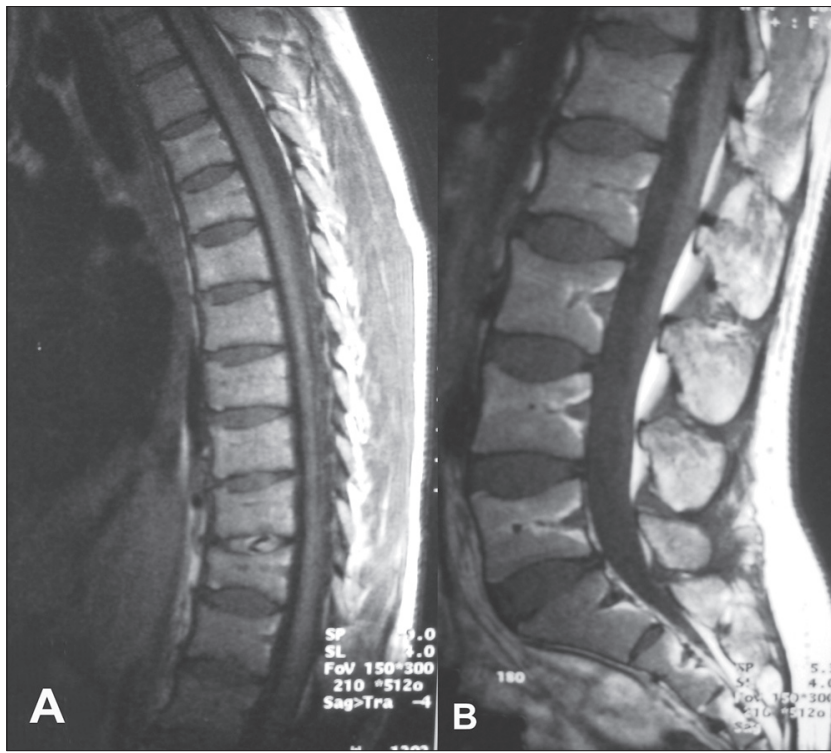

Figure 1. Vertebral compression fractures in A: dorsal, B: lumbar vertebrae seen in the T1-weighed sagittal MRI image of the case 1

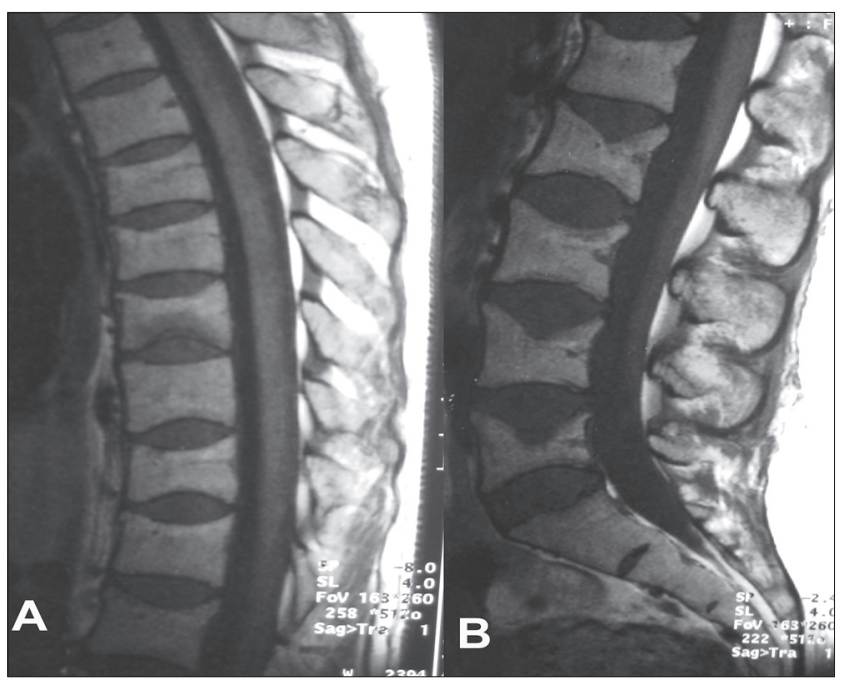

Figure 2. Compression fractures are seen in A: dorsal, B: lumbar T1-weighed sagittal MRI image of the case 2

muscles. Increased production of relaxin contributes to these changes $(9,10)$. The frequency of back pain in pregnancy differs from $24 \%$ to $56 \%$, and it is reported $54 \%$ at the 3 months postpartum period $(9,11,12)$.

We report two puerperant women, who were previously healthy and had no disease known to affect bone metabolism, experiencing low back pain and vertebral fractures during lactation.

Among the causes of low back pain in the postpartum period PPSO is a rare one. Although pregnancy is not known to be a cause for osteoporosis, PPSO and transient osteoporosis of the hip are rare conditions representing with osteoporosis associated with pregnancy (1). 
It is known that normal adaptive mechanisms during pregnancy and lactation allow adequate delivery of mineral to the fetus or infant and at the same time aim to protect the maternal skeleton. There appears to be little loss of mineral in the maternal skeleton with lactation of well nourished women in case, during or after lactation, menstrual cycle is reestablished. Extended lactation leads to acute skeletal loss despite high dietary calcium intake (13).

Although several factors are considered to cause PPSO, the etiology is not fully understood. Poor general nutrition, low calcium intake, a positive family history of osteoporosis and low vertebral BMD appear to be strong risk factors for PPSO $(1,12,14)$. In our cases there was no known history of osteoporosis determined by DXA, or osteoporotic fractures in the families. Only the first patient reported a low intake of calcium. PPSO is usually observed in primigravid, thinly built and lactating women (15), both of our patients were primigravid, thinly built and lactating.

Patients with PPSO have low BMD in the spine and proximal femur; appendicular BMD is usually normal (1). Spine scores are usually lower than hip scores (3). Both the hip and spine BMD values were osteoporotic in both of our patients; and their lumbar scores were lower than the hip scores.

Although the mechanism of action is not fully understood, calcium, vitamin D and antiresorptive agents are recommended in the treatment of PPSO $(1,3,8,15)$. The disease is usually a self limiting condition and tends not to recur in subsequent pregnancies. Cessation of lactation is also recommended as one of the therapeutic interventions to accelerate recovery (1). Both of our patients were treated with antiresorptive drugs (1st with calcitonin, $2^{\text {nd }}$ with alendronate); the patients were informed about weaning and stopped lactating. Their clinical complaints resolved with the treatment. Although bisphosphanate use is reported in limited series of PPSO patients (3), the data on long term safety in fertile women are limited (8). Since the $1^{\text {st }}$ patient planned to have another child calcitonin was prescribed. A patient successfully treated with strontium ranelate has been reported recently $(8,16)$; future studies data on safety and effectiveness of the chosen medication-either bisphosphanates or other- are needed.

PPSO leads to considerable morbidity with pain related disability. Back pain and loss of height in a postpartum woman should alert the physician about PPSO.

\section{Conflict of Interest}

No conflict of interest is declared by the authors.

\section{References}

1. Kohlmeier L, Marcus R. Osteoporosis associated with pregnancy. In: Marcus R, Feldman D, Kelsey J (eds) Osteoporosis. San Diego: Academic Press, 2001: 341-9.

2. Philips AJ, Ostlere SJ, Smith R. Pregnancy associated osteoporosis: does the skeleton recover? Osteoporosis Int 2000; 11: 449-54.

3. O'Sullivan $S M$, Grey $A B$, Singh R, Reid IR. Bisphosphonates in pregnancy and lactation-associated osteoporosis. Osteoporosis Int 2006; 17: 1008-12.

4. Sarikaya S, Ozdolap S, Açıkgöz G, Erdem CZ. Pregnancyassociated osteoporosis with vertebral fractures and scoliosis. Joint Bone Spine 2004; 71: 84-5.

5. Sarı H, Akarırmak U. Gebelikte osteoporoz. Osteoporoz Dünyasından 2000; 6: 129-33.

6. Özbek G, Reșorlu H, Karatepe AG, Kaya T, Günaydın R, Özer $\mathrm{N}$, ve ark. Gebeliğe bağlı osteoporoz: Olgu sunumu. Osteoporoz Dünyasından 2006; 12: 39-42.

7. Ofluoglu O, Ofluoglu D. A case report: pregnancy-induced severe osyeoporosis with eight vertebral fractures. Rheumatol Int 2008; 29: 197-201.

8. Tanriover MD, Oz SG, Sozen T, Kilicarslan A, Guven GS. Pregnancy- and lactation-associated osteoporosis with severe vertebral deformities: can strontium ranelate be a new alternative for the treatment? Spine J 2009; 9: e20-e24.

9. Colliton J. Managing back pain during pregnancy. Medscape Womens Health 1997; 2: 2.

10. Barr KP, Harrast MA. Low back pain. In: Braddom RL (ed). Physical Medicine and Rehabilitation. Philadelphia: Saunders Elservier, 2007: 883-927.

11. Lindal E, Hauksson A, Sigrun Arnardottir S, Hallgrimsson JPs. Low back pain, smoking and employment during pregnancy and after delivery-a 3-month follow-up study. J Obstet Gynaecol 2000; 20: 263-6.

12. To WW, Wong MW. Factors associated with back pain symptoms in pregnancy and persistence of pain 2 years after pregnancy. Acta Obstet Gynecol Scand 2003; 82: 1086-91.

13. Sowers MF. Premenopausal reproductive and hormonal characteristics and the risk for osteoporosis. In: Marcus R, Feldman D, Kelsey J (eds). Osteoporosis. San Diego: Academic Press, 2001: 721-40.

14. Di Gregorio S, Danilowicz K, Rubin Z, Mautalen C. Osteoporosis with vertebral fractures associated with pregnancy and lactation. Nutrition 2000; 16: 1052-5.

15. Tran HA, Petrovsky N. Pregnancy-associated osteoporosis with hypercalcaemia. Intern Med J 2002; 32: 481-5.

16. Fleisch H. Basic biology of bisphosphanates. In: Marcus R, Feldman D, Kelsey J (eds) Osteoporosis. San Diego: Academic Press, 2001; 449-68. 